\title{
DEVELOPMENT OF SOFT SKILLS AND HARD SKILLS FOR CLEANING STAFF: STUDY ON CLEANLINESS OF PRIVATE UNIVERSITIES IN SURABAYA
}

\author{
Venny Soetedja \\ Universitas Ciputra, UC Town, Citraland, Surabaya 60219, Indonesia
}

\begin{abstract}
Improving hard skills and soft skills can be done through appropriate and well-scheduled training. So, the purpose of this study is to look at differences in increasing the competence of hard skills and soft skills in cleaning staff at private universities through learning control classes and experimental classes. The method used is a quasi-experimental design with the Non-Equivalent Control Group Design. Respondents in this study were 50 cleaning staff of a private university in Surabaya, Indonesia. The results showed that the achievement of the experimental class assessment is significantly different compared to the achievement of the control class assessment regarding soft skills and hard skills.
\end{abstract}

Keywords: hard skills; soft skills; competences; training, cleaning staff; quasi-experimental

\section{INTRODUCTION}

Cleanliness is a representation of the performance results of cleaning staff who are present and on duty at a location, as well as being a joint contribution in maintaining environmental quality by all users. The cleanliness of the university environment is very influential on the overall educational activities that are running, so the entire university academic community has a big hand in creating a university that is clean from all impurities, comfortable, and safe from all distractions. The conducive atmosphere at work is inseparable from the skills of the cleaners in responding to the increasing challenges of cleanliness in the future. The need for these skills changes with the times. The rapid progress of

\footnotetext{
*Corresponding Author.

e-mail: venny.soetedja@ciputra.ac.id
} 
technology and the demands of the job must be balanced with an improvement in the soft skills and hard skills of each worker.

Soft skills have been highlighted in the needs of companies in the industrial revolution era. Researchers say that the dominant skill which determines success is not hard skills (technical skills), but self-quality in the category of soft skills or skills related to interactions with others (people skills) (Rakim et al, 2017). However, the reality is that over time the number of workers with good soft skills tend to decrease. This happens because companies are increasingly having trouble finding workers who have good soft skills. The development of soft skills is a joint responsibility of the company and the community. The aspect of soft skills is not yet optimal for workers in the industrial world because the process of implementation and learning is still oriented on hard skills (Delita et al, 2016). Several findings indicate the prioritized needs for soft skills in the service industry, one of which is for cleaning staff, such as competence, communication skills, integrity, discipline, and cooperation (Suryanto et al., 2014).

Workers' competencies cannot be built by themselves through work experience or short training that the worker has participated in without considering the area of work they encountered. Work competency perspective is often debated by employers and work service providers. This condition is used as a benchmark for the professionalism of the work service providers by the employer which often leads to the legal termination of employment contract.

Communication skills, part of soft skills, are fundamental for a worker (PopescuMitroi et al., 2015). Communication skills are a prerequisite for professional success; therefore, worker communication competency is mandatory for cleaning staff in order to be able to accept and express opinions to consumers and superiors in carrying out their work. Communication as a medium of interaction must be supported by information integrity and good teamwork. Teamwork in the cleaning workforce will create a conducive working condition that are faster and optimal. Thus, this form of cooperation is important to maintain.

Based on the reality, training is needed to balance the aspects needed by workers for the present and the future, for both soft skills and hard skills. Therefore, the purpose of this study is to see the extent to which there is an increase in the competence of soft skills and hard skills through competency enhancement training with an experimental study approach to university cleaning service staff. 
Several previous studies on soft skills and hard skills conducted researches with the same process for all respondents and assessed the results (Delita et al., 2016; Kusmiran, 2017), and conducted a pre-test and post-test after training (Darmiany, 2016). Therefore, this research is planned to be done by dividing respondents into two groups, and training is provided with two different training processes for each group. The training material provided is the same but different training processes are used during the training period, and after the training is finished the results of the two groups are measured and compared.

\section{LITERATURE REVIEW}

Work competence is closely related to the working ability of each individual which includes aspects of knowledge, skills, and working attitudes that are in accordance with the standards set by the company. Competence is often seen as the ability to carry out work-related technical tasks that can be observed (observed performance) as well as intellectual and mental emotional basic abilities (key competencies) that are needed for the development of professional attitudes in work and the development of aspects in broader life, such as being sensitive and responsive to various things that occur, being rational, independence, and the ability to work together (Baum, 1990).

In general, competencies are divided into two types, namely Core Competency and Specific Competency (Adomssent et al, 2007). Core Competency is the competency needed by all fields of work. Every worker needs to have this core competency. Specific Competency is the competency needed by each specific field of work. In general, the recruitment selection of prospective workers is assessed from the competencies of hard skills and soft skills. A prospective workforce who has better competence and job readiness compared to others will win the competition in getting a job.

Hard skills are technical skills that are inherent or needed for certain professions. Hard skills are definitely needed to be able to work according to purpose. Hard skills are also related to the core competencies of workers, especially for the cleaning staff in this case. Hard skills or hard competencies are competencies that are defined as a standard of what someone must know or do in order to carry out their work properly. Technical competence generally makes 
it easier for employees to do standard and unchanging technical work with clear standards (Kusmiran, 2017). For example, the work done in the field of cleanliness is about cleaning the work area with the best time and maximum results. With the abilities mentioned above, they can work with a high level of efficiency and quality because they relate to the field of human resources. Hard skill competencies are usually associated with one's work performance. The concentration of technical competence is on the workers, namely describing the responsibilities, challenges, and work targets that must be done or achieved by workers/employees so that they can perform well.

The demand for the world of work on the criteria for prospective workers tends to be even higher. The world of work does not only prioritize high academic skills (hard skills), but also pays attention to skills in terms of values inherent in a person or often known as aspects of soft skills. Soft skills or soft competencies are basic competencies that describe how a person behaves in order to carry out his work well (Robles, 2012). This competency emphasizes the productive behavior that must be possessed and demonstrated by someone in carrying out a job in order to perform well. If someone has this competency, then that person will excel better than someone who does not have soft skill competence. Soft skills are basically personal skills, such as special skills that are non-technical, intangible, and personality that determine a person's strength as a leader, a listener, a negotiator, and a mediator of conflict (Whitehurst, 2016). It is also called as interpersonal skills, including the ability to communicate and work together in groups.

Measurement of the Soft Skills and Hard Skills of cleaning staff on aspects of work readiness and work ability can be done by an experimental method. The first stage is giving a pre-test at the beginning of the activity. The second phase is soft skills training and hard skills training for cleaning staff to improve their competencies. In the third stage, measurements were taken in the form of a posttest to describe the soft skills and hard skills competencies of the cleaning staff.

\section{RESEARCH METHODOLOGY}

This study uses a quasi-experimental research method with the NonEquivalent Control Group Design. Experimental research methods can be inter- 
preted as "research methods used to look for the effect of certain treatments on others under controlled conditions" (Heinz et al, 2004). The population in this study was the cleaning staff who served at Ciputra University Surabaya, selected using the census sample technique. Census sample technique is a data collection method that considers all members of the population to be research samples. The sample in this study amounted to 50 people with the details of group A consisting of as many as 25 people as the experimental group and group B consisting of as many as 25 people as the control group. Data collection techniques are done using test instruments and observation sheets.

An experimental design is a conceptual framework for conducting experiments. A design has a function to create conditions for comparisons needed by the experimental hypothesis and through statistical data analysis which allows researchers to make meaningful interpretations of the results of the investigation (Allegranzi et al, 2013). The form of research design used was quasi-experimental design. This design has a control group, but it cannot function fully to control the external variables that affect the execution of the experiment. However, this design is better than the pre-experimental design.

This Quasi Experimental study involved two groups of samples, namely the experimental group and the control group. The experimental group is the group that gets the treatment, namely the cleaning service group that follows the learning using the experimental and interactive methods, while the control group is the cleaning service group who follows the learning without the experimental and interactive methods.

The design used in this study is Quasi Experimental Design in the form of Non-Equivalent Control Group Design. This design is almost the same as the pre-test and post-test control group design, only in this design the experimental group and the control group are not randomly selected. In this design, both the experimental group and the control group are compared, selected, and placed without going through randomization. Both groups were given a pre-test to find out their initial conditions to see the difference between the experimental class and the control class. A good pre-test result is if the pre-test value of the experimental class and the control class do not differ significantly. This research design is in the form of: 


\section{Nonequivalent Control Group Design}

$$
\begin{array}{llll}
\mathrm{E} & \mathrm{O} 1 & \mathrm{X} & \mathrm{O} 2 \\
\mathrm{~K} & \mathrm{O} 3 & & \mathrm{O} 4
\end{array}
$$

Remarks:

$\mathrm{E}$ is the Experimental Group

$\mathrm{K}$ is the CoOntrol Group

$\mathrm{O} 1$ and $\mathrm{O} 3=$ Pre-Test

$\mathrm{O} 2$ and $\mathrm{O} 4=$ Post-Test

$\mathrm{X}=$ Treatment towards the Experimental Group

\section{RESEARCH RESULTS}

This research was conducted to determine the effect of teaching methods on soft skills and hard skills of the cleaning staff of Ciputra University in Surabaya. In this study, the population is divided into two classes as research samples. One class becomes the experimental class and another class becomes the control class. The experimental class received treatment in the form of experimental and interactive learning methods, while the control class did not receive special treatment and thus only received normal treatment, which is conventional learning.

Data obtained from the results of this study are quantitative and qualitative data. The quantitative data presented are data on the understanding of cleaning staff regarding soft skills and hard skills, while the qualitative data presented is the result of observations of the implementation of experimental methods in the experimental class. The experimental class consisted of 25 cleaning staff while the control class consisted of 25 cleaning staff. The data obtained from cleaning staff who took the pre-test and post-test in each class is expressed in a Likert scale of 1 to 5 .

After researchers obtained the data, then the data are analyzed to draw conclusions. Quantitative data processing is done using the help of a calculating software. Qualitative data is collected through observation of the learning process by using the experimental method in the experimental class. 
A description of the results of the pre-test competencies of soft skills and hard skills on cleaning staff

The description of the pre-test data on the results of soft skills and hard skills competencies illustrates the initial understanding of cleanliness. The total score for each respondent was obtained from the pre-test results of the experimental and control classes. The data of the pre-test competencies of soft skills and hard skills were obtained from the answers of the cleaning staff in the experimental class and the control class. The results of the pre-test competency of soft skills and hard skills are as follows:

Table 1 Interval Categories Pre-Test Competencies of Soft Skills and Hard Skills

\begin{tabular}{clcccc}
\hline \multirow{2}{*}{$\begin{array}{c}\text { Likert } \\
\text { Scale }\end{array}$} & \multirow{2}{*}{ Description } & \multicolumn{2}{c}{ Soft Skill Percentage } & \multicolumn{2}{c}{ Hard Skill Percentage } \\
\cline { 3 - 6 } & & Experimental & Control & Experimental & Control \\
\hline 5 & Very Capable & 0 & 0 & 0 & 0 \\
4 & Capable & $36.72 \%$ & $34.51 \%$ & $29 \%$ & $31 \%$ \\
3 & Able & $61.11 \%$ & $61.13 \%$ & $71 \%$ & $69 \%$ \\
2 & Incapable & $2.18 \%$ & $4.36 \%$ & $0 \%$ & 0 \\
1 & Very Incapable & 0 & 0 & 0 & 0 \\
\hline
\end{tabular}

The initial understanding of soft skills and hard skills competencies obtained from the pre-test results in the experimental and control classes is shown in Table 1. In the aspects of the experimental group soft skills, $36.72 \%$ stated that they were Capable, $61.11 \%$ stated that they were Able, and $2.18 \%$ said they were Incapable. This is different from the control class, in which $34.51 \%$ said they were Capable, 61.13 stated they were Able, and 4.36\% said they were Incapable. The results of the interim conclusions stated that the experimental class were higher than the control class in the soft skill competency aspect. In the aspect of hard skills, the experimental class $29 \%$ stated as Capable, and $71 \%$ stated as Able. In contrast to the control class, 31\% stated Capable and 69\% stated Able. Preliminary results concluded that the control class was higher in value than the experimental class on the hard skill aspect. 
Table 2 Descriptive Statistics of Pre-test Scores for Soft Skill and Hard Skill Competencies

\begin{tabular}{lccccc}
\hline & \multicolumn{5}{c}{ Descriptive Statistics } \\
& Min & Max & Mean & Std & Variance \\
\hline Experimental & & 4 & 3.36 & 0.510 & 0.260 \\
Soft Skill & 3 & 4 & 3.32 & 0.476 & 0.227 \\
Hard Skill & 3 & & & & \\
Control & & 4 & 3.24 & 0.63 & 0.440 \\
Soft Skill & 3 & 4 & 3.28 & 0.458 & 0.210 \\
Hard Skill & 3 & & & & \\
\hline
\end{tabular}

The descriptive statistics of the pre-test scores of aspects of soft skill and hard skill competency in the experimental and control classes are shown in Table 2.

Table 3 Interval Categories Post-Test Competencies Soft Skills and Hard Skills

\begin{tabular}{clcccc}
\hline \multirow{2}{*}{$\begin{array}{c}\text { Skala } \\
\text { Likert }\end{array}$} & Description & \multicolumn{2}{c}{ Soft Skill Percentage } & \multicolumn{2}{c}{ Hard Skill Percentage } \\
\cline { 3 - 6 } & & Experimental & Control & Experimental & Control \\
\hline 5 & Very Capable & $38.90 \%$ & $14 \%$ & $29 \%$ & $19 \%$ \\
4 & Capable & $41.10 \%$ & $43 \%$ & $57 \%$ & $32 \%$ \\
3 & Able & $20 \%$ & $43 \%$ & $14 \%$ & $49 \%$ \\
2 & Incapable & 0 & 0 & 0 & 0 \\
1 & Very Incapable & 0 & 0 & 0 & 0 \\
\hline
\end{tabular}

The final understanding of soft skills and hard skills competencies obtained from the pre-test results in the experimental and control classes is shown in Table 3. In the aspects of the soft skills of the experimental class, $38.9 \%$ stated that they were Very Capable, $41.10 \%$ said they were Capable and 20\% stated that they were Able. This is different from the control class where $29 \%$ said they were Very Capable, 57\% said they were Capable, and 14\% said they were Able. The results of the interim conclusions is the experimental class were higher than the control class in the soft skill competency aspect. In the aspect of hard skills, in the experimental class 14\% stated as Very Capable, $41 \%$ were Capable, and 43\% stated as Able. In contrast, in the control class 19\% stated as Very Capable, 32\% as Capable, and $49 \%$ as Able. Preliminary results concluded that the experimental class was higher in value than the control class on the hard skill aspect. 
Table 4 Descriptive Statistics of Post-test Scores on Soft Skill and Hard Skill Competencies

\begin{tabular}{|c|c|c|c|c|c|}
\hline \multicolumn{6}{|c|}{ Descriptive Statistics } \\
\hline & Min & Max & Mean & Std & Variance \\
\hline \multicolumn{6}{|c|}{ Experimental } \\
\hline Soft Skill & 3 & 5 & 4.28 & 0.614 & 0.377 \\
\hline Hard Skill & 3 & 5 & 3.80 & 0.816 & 0.667 \\
\hline \multicolumn{6}{|l|}{ Control } \\
\hline Soft Skill & 3 & 5 & 4.12 & 0.781 & 0.610 \\
\hline Hard Skill & 3 & 5 & 4.24 & 0.712 & 0.507 \\
\hline
\end{tabular}

The descriptive statistics of the pre-test scores of soft skill and hard skill competency aspects in both experimental and control classes are shown in Table 4.

Based on the test results, the t-test of pre-test to post-test on Soft Skill and Hard Skill competencies in the control class shows the value of Levene's Test as $0,000<0.05$. Thus, it can be interpreted that the data variance between the pretest and the post-test on Soft Skill and Hard Skill competencies is heterogeneous or different. The results of the Sig. ( 2 tailed) is $0,000<0.05$. Thus, it can be concluded that there is a significant (real) difference in the control class between the pre-test and post-test results on the competence of Soft Skills and Hard Skills.

Furthermore, the t-test pre-test to the post-test results on the Soft Skill and Hard Skill competencies in the experimental class showed the Levene's Test value of $0.065>0.05$. This can be interpreted that the data variance between the pretest and post-test on Soft Skill and Hard Skill competencies is homogeneous or the same. The results of the Sig. ( 2 tailed) is $0.065>0.05$. This can be concluded that there is no significant (real) difference in the experimental class between the pre-test and post-test results on the competence of Soft Skills and Hard Skills.

\section{DISCUSSION OF RESEARCH RESULTS}

This study uses 50 respondents and divides the 50 respondents into two groups with an equal number of 25 people in the experimental class and 25 people in the control class. Both the experimental class and the control class were given different treatments but were given the same pre-test and post-test to measure the competencies of soft-skills and hard skills, then the results of pretest and post-test between the two are compared. 
This study compares the soft skills and hard skills competencies in the experimental class and the control class, where the pre-test and post-test are conducted in both classes. Pre-test results on the soft skills of the experimental class and the control class showed results that were not much different, whereas the most respondents in both classes stated that they were quite capable in soft skills competence.

Table 5 Comparison of Interval Categories Pre-Test and Post-Test Competencies of Soft Skills

\begin{tabular}{|c|c|c|c|c|c|}
\hline \multirow{2}{*}{$\begin{array}{l}\text { Likert } \\
\text { Scale }\end{array}$} & \multirow[t]{2}{*}{ Description } & \multicolumn{2}{|c|}{$\begin{array}{c}\text { Soft Skills } \\
\text { Experiment Group }\end{array}$} & \multicolumn{2}{|c|}{$\begin{array}{c}\text { Soft Skills } \\
\text { Control Group }\end{array}$} \\
\hline & & Pre-Test & Post-Test & Pre-Test & Post-Test \\
\hline 5 & Very Capable & 0 & $38.90 \%$ & 0 & $14 \%$ \\
\hline 4 & Capable & $36.72 \%$ & $41.10 \%$ & $34.51 \%$ & $43 \%$ \\
\hline 3 & Able & $61.11 \%$ & $20.00 \%$ & $61.13 \%$ & $43 \%$ \\
\hline 2 & Not Capable & $2.18 \%$ & 0 & $4.36 \%$ & 0 \\
\hline 1 & Very Poor & 0 & 0 & 0 & 0 \\
\hline
\end{tabular}

The results of the pre-test on the hard skills of the experimental class and the control class showed more similar results, where respondents in both classes chose only two choices from the five choices in the Likert scale, which are, Capable and Able with similar values in both groups. The results of the pre-test for soft skills and hard skills in this study are good and in line with the expectations in the experimental design research, where it is stated that good pre-test results is if the pre-test scores in the experimental and control classes are not significantly different.

Table 6 Comparison of Interval Categories Pre-Test and Post-Test Competencies of Hard Skills

\begin{tabular}{clcccc}
\hline \multirow{2}{*}{\begin{tabular}{l}
\multirow{2}{*}{$\begin{array}{l}\text { Likert } \\
\text { Scale }\end{array}$} \\
\end{tabular}} & Description & \multicolumn{2}{c}{$\begin{array}{c}\text { Hard Skills } \\
\text { Experiment Group }\end{array}$} & \multicolumn{2}{c}{$\begin{array}{c}\text { Hard Skills } \\
\text { Control Group }\end{array}$} \\
\cline { 3 - 6 } & & Pre-Test & Post-Test & Pre-Test & Post-Test \\
\hline 5 & Very Capable & 0 & $38.90 \%$ & 0 & $19.00 \%$ \\
4 & Capable & $29.00 \%$ & $41.10 \%$ & $31.00 \%$ & $32.00 \%$ \\
3 & Able & $71.00 \%$ & $20.00 \%$ & $69.00 \%$ & $49.00 \%$ \\
2 & Not Capable & 0 & 0 & 0 & 0 \\
1 & Very Poor & 0 & 0 & 0 & 0 \\
\hline
\end{tabular}


The results comparing the post-test results for soft skills and hard skills between the experimental class and the control class in this study showed quite varied results compared to the pre-test results, which tended to be not much different. The post-test results on the soft skills of the experimental class showed different results from the control class, as the results were higher in the experimental class. The experimental class respondents showed a sufficiently high score on the Very Capable response of the soft skills of the post-test with $38.90 \%$, whereas in the pre-test there was $0 \%$, which indicated that they grew into very capable individuals. Whereas in the control class, the results are $43 \%$ stating Able and 43\% Capable while in the very capable section is $14 \%$, which is an increase from nothing at all $(0 \%)$ in the pre-test. There is a significant difference between the pre-test and post-test results of the hard skills competencies in the experimental class and the control class.

In the post-test results, in comparison between the hard skills competence between the experimental class and the control class, there is a higher competency increase in the experimental class compared to the control class. In the experimental class, the hard skills competency experienced a significant increase compared to the pre-test. The results show an increase in Mean, Standard Deviation, and Variance between the pre-test and post-test on the soft skills and hard skills competencies of cleaning staff at private universities in Surabaya.

Table 7 Comparison of Statistic Descriptive on Pre-test and Post-test Scores on Soft Skills dan Hard Skills Competencies

\begin{tabular}{lcccccc}
\hline & & \multicolumn{5}{c}{ Statistics Descriptive } \\
& Mean & $\frac{\text { Pre-Test }}{\text { Std }}$ & Variance & Mean & $\frac{1}{\text { Post-Test }}$ & \\
\cline { 1 - 2 } Experiments Group & & & & & & \\
Soft Skill & 3.36 & 0.510 & 0.260 & 4.28 & 0.614 & 0.377 \\
Hard Skill & 3.32 & 0.476 & 0.227 & 3.80 & 0.816 & 0.667 \\
Control Group & & & & & & \\
Soft Skill & 3.24 & 0.63 & 0.440 & 4.12 & 0.781 & 0.610 \\
Hard Skill & 3.28 & 0.458 & 0.210 & 4.24 & 0.712 & 0.507 \\
\hline
\end{tabular}

Statistically, the results of the t-test on the Levene Test have shown that homogeneous results were found, or there was no significant difference, between pre-test and post-test in the experimental class on soft skills and hard skills 
competencies of cleaning staff at a private university in Surabaya. Whereas the control class showed heterogeneous results, or there was a significant difference, between the pre-test and post-test on the soft skills and hard skills competencies of cleaning staff at a private university in Surabaya.

\section{CONCLUSION}

This study aims to compare the competencies of soft skills and hard skills in training with the experimental class and the control class in the cleaning staff of a private university in Surabaya. The research results obtained are based on the results of the analysis and discussion conducted. The assessment results of the experimental class have a significant difference compared to the assessment results of the control class. According to the results of the experimental class research, it can be interpreted that the variance of the data between pre-test and post-test on Soft Skill and Hard Skill competencies is homogeneous or the same. It can thus be concluded that there is no significant (real) difference in the experimental class between the pre-test and post-test results on the competence of Soft Skills and Hard Skills.

In the control class, it can be concluded that the variance of data between pre-test and post-test on Soft Skill and Hard Skill competencies is heterogeneous or different. It can be concluded that there is a significant (real) difference in the control class between the pre-test and post-test results on the competence of Soft Skills and Hard Skills. Observation results show that in the experimental class, learning is done in groups so that the cleaning staff have an increased ability of Hard Skills and Soft Skills to support the quality of individual and group work. Broadly speaking, an increase in hard skills and soft skills can be obtained through appropriate and well-scheduled training.

Research by Rakim et al. (2017) stated that the rapid technological advancement and demands of work must be balanced with an increase in the soft skills and hard skills possessed by each worker, including in the field of cleaning business. Training to improve soft skills and hard skills conducted in this study shows that training with control classes that use conventional training methods results are more heterogeneous compared to more interactive experimental 
classes where the results are more homogeneous as seen from the achievement of pre-test and post-test assessments.

The final conclusion of this study is that the improvement of soft skills and hard skills in cleaning staff at universities is indicated by the results of $t$-count greater than t-table, so it can be concluded that the training provided is effective in improving the skills of cleaning staff at the university. This is in line with the results put forward by several previous researchers, including by Rakim et al. (2017) and Delita et al. (2016).

\section{IMPLICATIONS}

The results of this study show how important it is to conduct training for cleaning staff who either work in private universities or in other public places. This research supports other past researches by (Rakim et al. 2017; Delita et al., 2016; Darmiany, 2016) which showed that the results of training can always improve the skills and competencies of trainees. This research also supports Kusmiran's research (2017) which stated that effective training increases the ability of workers' soft skills. However, in reality cleaning staff rarely get the training they really need. The cleaning service provider company should be more aware that the competence of its workers will largely determine the quality of the work that will ultimately show the performance of the company as assessed by the employer.

The implication that can be suggested for employer companies is that they should conduct routine training for skills and competencies, in both soft skills and hard skills. Judging by Robles's opinion (2012), which stated that in modern times technical skills or hard skills alone is not enough to keep a job when there is a reduction in the number of employees, but soft skills become a more decisive factor for both the present and in the future (James \& James, 2004; Nealy, 2005). Some of these things underlie the opinion of Suryanto et al. (2014) which stated that soft skills play a more important role, especially in services, so that they can be a reference for employers providing cleaning staff with more soft skills training, especially communication skills according to Popescu-Mitroi et al. (2015). 
Future studies need to examine further about how much a particular type of training is able to give effect in the form of improving the skills and competencies of employees. It also needs to be further investigated regarding the effects of training on different fields of work.

\section{REFERENCES}

Adomssent, M., Godemann, J., Michelsen, G., Barth, M., Rieckmann, M., \& Stoltenberg, U. 2007. Developing key competencies for sustainable development in higher education. International Journal of Sustainability in Higher Education, 8(4), 416-430. https://doi.org/10.1108/14676370710823582.

Allegranzi, B., Gayet-Ageron, A., Damani, N., Bengaly, L., McLaws, M.L., Moro, M.L., \& Donaldson, L. 2013. Global implementation of WHO's multimodal strategy for improvement of hand hygiene: A quasi-experimental study. The Lancet Infectious Diseases, 13(10), 843-851. https://doi.org/10.1016/S14733099(13)70163-4.

Baum, Tom. 1990. Competencies for Hotel Management: Industry Expectations of Education. International Journal of Contemporary Hospitality Management, 2(4),13-20.

Darmiany, A. 2016. Pengembangan Model Pelatihan Soft-skills pada Siswa Sekolah Menengah Pertama Negeri (SMPN) di Kota Mataram. Jurnal Kajian Bimbingan dan Konseling, 1(2), 47-54. http://dx.doi.org/10.17977/ um001v1i22016p047.

Delita, F., Yetti, E., \& Sidauruk, T. 2016. Peningkatan Soft Skills Dan Hard Skills Mahasiswa Melalui Project-Based Learning pada Mata Kuliah Perencanaan Pembelajaran Geografi. Journal Geografi Universitas Negeri Medan, 8(2), 124-135. Retrieved from http://jurnal.unimed.ac.id/2012/index.php/geo/ article/ download/5776/5172.

Heinz, O., Ilyushin, B., \& Markovich, D. 2004. Application of a PDF Method for the Statistical Processing of Experimental Data. International Journal of Heat and Fluid Flow, 25(5), 864-874. https://doi.org/10.1016/j.ijheatfluidflow.2004.05.009.

James, R.F. \& James, M.L. 2004. Teaching Career and Technical Skills in a “Mini” Business World. Business Education Forum, 59(2), 39-41. 
Kusmiran, E. 2017. Pelatihan Soft Skills Caring Meningkatkan Kualitas Pelayanan Keperawatan dan Kepuasan Pasien di Rumah Sakit Kota Bandung. Jurnal Penelitian dan Pengembangan Pelayanan Kesehatan, 1(2), 72-81. https:// doi.org/10.22435/jpppk.v1i2.440.

Popescu-Mitroi, M.M., Todorescu, L.L., \& Greculescu, A. 2015. The Impact of Psycho-Pedagogical Training on Communicative Competence. ProcediaSocial and Behavioral Sciences, 191, 2443-2447. https://doi.org/10.1016/ j.sbspro.2015.04.723.

Nealy, C. 2005. Integrating Soft Skills through Active Learning in the Management Classroom. Journal of College Teaching \& Learning, 2(4), 1-6. https:/ /doi.org/10.19030/tlc.v2i4.1805.

Rakim, R., Wilonoyudho, S., \& Widjanarko, D. 2017. Penerapan Model Pembelajaran Shesil (Soft, Hard, and Environment Skill Integrated Learning) pada Kecakapan Otomotif. Journal of Vocational and Career Education, 2(2). https://doi.org/10.15294/jvce.v2i2.13835.

Robles, M.M. 2012. Executive Perceptions of the Top 10 Soft Skills Needed in Today's Workplace. Business Communication Quarterly, 75(4), 453-465. https://doi.org/10.1177/1080569912460400.

Suryanto, D., Kamdi, W., \& Sutrisno, S. 2014. Relevansi Soft Skill yang Dibutuhkan Dunia Usaha/Industri dengan yang Dibelajarkan di Sekolah Menengah Kejuruan. Teknologi Kejuruan: Jurnal Teknologi, Kejuruan, dan Pengajarannya, 36(2). 107-118. http://dx.doi.org/10.17977/tk.v36i2.3811 Whitehurst, G.J. 2016. Hard thinking on soft-skills. Evidence Speaks Reports, Vol. 1,\# 14.Center on Children and Families at Brookings. Brookings Institution, 1, 1-10. 
Review of Management and Entrepreneurship

Volume 04, Number 01, April 2020 